\title{
Removal of enteric viruses and Escherichia coli from municipal treated effluent by zebra mussels
}

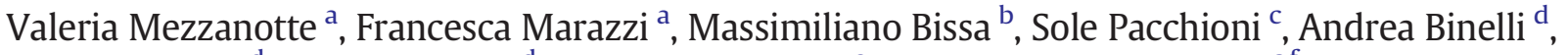 \\ Marco Parolini ${ }^{\mathrm{d}}$, Stefano Magni ${ }^{\mathrm{d}}$, Franco M. Ruggeri ${ }^{\mathrm{e}}$, Carlo De Giuli Morghen ${ }^{\mathrm{c}, \mathrm{f}}$, \\ Carlo Zanotto ${ }^{\mathrm{c}, 1}$, Antonia Radaelli ${ }^{\mathrm{b}, \mathrm{f}, *}$ \\ a Department of Earth and Environmental Sciences, University of Milan Bicocca, Piazza della Scienza, 1, 20126 Milan, Italy \\ ${ }^{b}$ Department of Pharmacological and Biomolecular Sciences, University of Milan, Via Balzaretti, 9, 20133 Milan, Italy \\ c Department of Medical Biotechnologies and Translational Medicine, University of Milan, Via Vanvitelli, 32, 20129 Milan, Italy \\ d Department of Biosciences, University of Milan, Via Celoria 26, 20133 Milan, Italy \\ e Department of Veterinary Public Health \& Food Safety, I.S.S., Viale Regina Elena 299, 00161 Rome, Italy \\ f CNR Institute of Neurosciences, Cellular and Molecular Pharmacology Section, University of Milan, Via Vanvitelli, 32, 20129 Milan, Italy
}

\section{H I G H L I G H T S}

- Polio and rotavirus titers are significantly reduced by zebra mussel biofiltration.

- E. coli counts are almost completely reduced by zebra mussels.

- A bioremediation strategy by zebra mussel biofiltration.

- Zebra mussel ability to filter/inactivate pathogens may control human health risks.

\section{A R T I C L E I N F O}

\section{Article history:}

Received 28 July 2015

Received in revised form 1 September 2015

Accepted 1 September 2015

Available online 12 September 2015

Editor: D. Barcelo

\section{Keywords:}

Wastewater bioremediation

Zebra mussel biofiltration

\section{G R A P H I C A L A B S T R A C T}

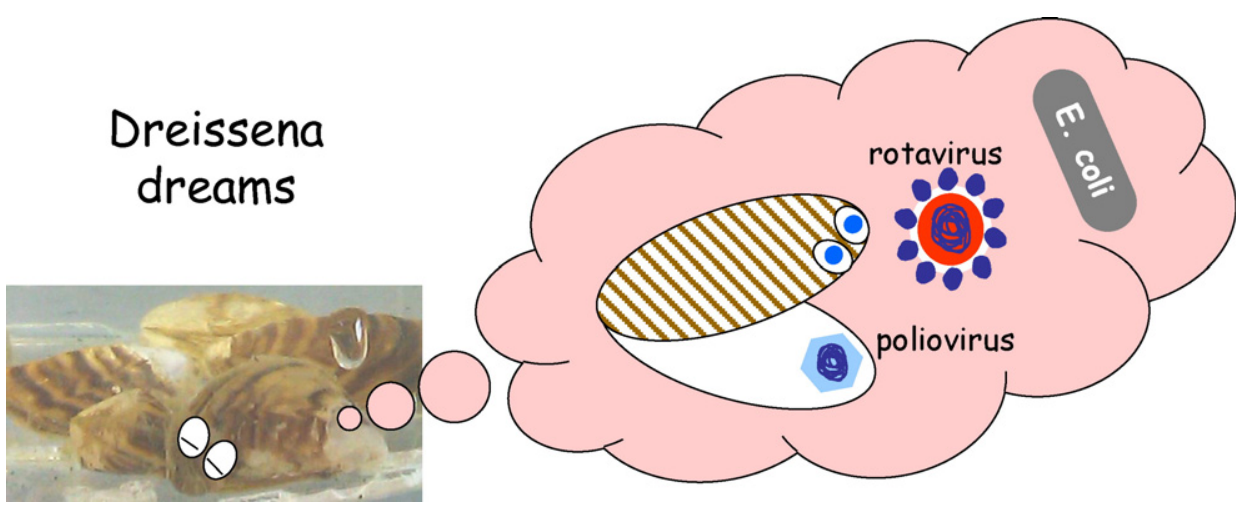

Dreissena polymorpha is a widespread filter-feeder species, resistant to a broad range of environmental conditions and different types of pollutants, which has recently colonized Italian freshwaters. Although widely used to monitor pollution in freshwater environments, this species is also an important food source for some fish and water birds. It can also be used to concentrate or remove particulate organic matter to interrupt avian-to-human transmission of pollutants and control health risks for animals and humans. In this study, the accumulation/inactivation in D. polymorpha of human health-related spiked enteric viruses was described. The removal of endogenous Escherichia coli, the classical indicator of fecal contamination, was tested as well. Our preliminary lab-scale results demonstrate that zebra mussels can reduce significantly poliovirus titer after $24 \mathrm{~h}$ and rotavirus titer after $8 \mathrm{~h}$. E. coli counts were also reduced in the presence of zebra mussels by about $1.5 \log$ after $4 \mathrm{~h}$ and nearly completely after $24 \mathrm{~h}$. The fate of the two enteric viruses after concentration by zebra mussels was also investigated after

\footnotetext{
* Corresponding author at: Department of Pharmacological and Biomolecular Sciences, University of Milan, Via Balzaretti, 9, 20133 Milan, Italy.

E-mail addresses: valeria.mezzanotte@unimib.it (V. Mezzanotte),fra.marazzi@gmail.com (F. Marazzi),massimiliano.bissa@unimi.it (M. Bissa),sole.pacchioni@studenti.unimi.it (S. Pacchioni), andrea.binelli@unimi.it (A. Binelli), marco.parolini@unimi.it (M. Parolini), stefano.magni@unimi.it (S. Magni), franco.ruggeri@iss.it (F.M. Ruggeri), carlo.degiulimorghen@unimi.it (C. De Giuli Morghen), carlo.zanotto@unimi.it (C. Zanotto), antonia.radaelli@unimi.it (A. Radaelli).

1 Co-last authors.
} 


\section{Introduction}

The zebra mussel Dreissena polymorpha (D. polymorpha) is a PontoCaspian zebra mussel bivalve species, that has invaded and colonized Italian freshwaters during the late 1980s (Schloesser and Schmuckal, 2013). Zebra mussels are small, sessile organisms, widespread filter feeders, resistant to a broad range of environmental conditions (Claudi and Mackie, 1993) and to different types of pollutants (Bervoets et al., 2005). They can concentrate particulate organic matter and indigestible components from water with a clearance rate ranging between 5 and $400 \mathrm{~mL} /$ individual/h (Ackerman, 1999; Baldwin et al., 2002). D. polymorpha have their most suitable habitat in stable riverbeds under high flows, a velocity below $1.2 \mathrm{~m} / \mathrm{s}$, and a depth of less than $5 \mathrm{~m}$ under regular flows (Sanz-Ronda et al., 2014). They have been extensively used to monitor pollution in freshwaters, especially in bioaccumulation studies, by determining the level of pollutants in their soft tissues (Voets et al., 2006). The impact of river colonization by these mussels has been considered one of the most important ecological changes in freshwater systems, both for the drop in biodiversity and for the socio-economic problems they can cause (Sanz-Ronda et al., 2014; Stankovic and Jovic, 2013). The ability of zebra mussels to attach and foul structures has also caused problems in the withdrawal of drinking water and electric-power plants (Schloesser and Nalepa, 1994) and their ability to colonize the surfaces of all solid structures in the water have caused nuisances to fishermen (Schloesser and Nalepa, 1994). On the other hand, they have also modified the aquatic environment, making the habitat more suitable for themselves and other organisms (Stankovic and Jovic, 2013). When studying their influence on physical and chemical characteristics of the Zhrebchevo water reservoir (Bulgaria) during the periods before (1977-1980) and after (20092011) their invasion, water quality improved with a statistically significant effect on turbidity, $\mathrm{pH}$, concentrations of dissolved oxygen, and $\mathrm{NH}_{4}-\mathrm{N}, \mathrm{NO}_{2}-\mathrm{N}, \mathrm{NO}_{3}-\mathrm{N}$ (Kalchev et al., 2013). In particular, two different studies showed zebra mussels efficiency in nutrient (Piesik, 1983) and algae (Richter, 1986) removal.

Many works have also been published on the ability of zebra mussel to remove and accumulate chemical pollutants even when present at very low concentrations (De Jonge et al., 2012; Peck et al., 2007; Voets et al., 2006). Very recently, it was also demonstrated the role played by zebra mussel biofiltration in decreasing the concentration of many pharmaceuticals and traces of metals from wastewaters (Binelli et al., 2014; Magni et al., 2015).

However, in spite of the numerous data on the accumulation of chemical pollutants, only a few studies are available on the ability of D. polymorpha to remove microorganisms. Frischer et al. (2000) demonstrated that zebra mussels use bacteria as a food source and a recent study (Winters et al., 2011) analyzed the composition of the bacterial community in zebra mussels from three locations of the Great Lakes basin waters (Michigan, USA). Bacteria potentially pathogenic for aquatic and terrestrial animals, such as Aeromonas spp., Flavobacterium spp., Pseudomonas fluorescens, Shewanella putrefaciens and Shigella spp., were also detected after disrupting mussel tissues. Cryptosporidium parvum, Giardia duodenalis and Toxoplasma gondii oocysts were also found in tissues of zebra mussels exposed for one week to different protozoan concentrations, showing that their bioaccumulation was proportional to the environment contamination (Palos Ladeiro et al., 2014). Escherichia coli removal by oysters and hard shell clams (Love et al., 2010) as well as by common mussels (de Mesquita et al., 1991) has also been studied, and oysters or hard shell clams were also used for norovirus (Flannery et al., 2013), poliovirus, hepatitis A (Love et al.,
2010) or Norvalk virus removal (Schwab et al., 1998). However, to our knowledge, the accumulation of human health-related enteric viruses by zebra mussels from water was never described, the only one case referring to avian influenza virus (Faust et al., 2009).

The aim of this study was to evaluate whether zebra mussels could remove the residual load of fecal bacteria and enteric viruses from treated effluents of a municipal wastewater treatment plant (WWTP) to decrease public health risks, especially in effluent dominated streams. Therefore, a series of lab-scale experiments have been carried out to verify the ability of $D$. polymorpha to remove endogenous $E$. coli and two enteric viruses (poliovirus and rotavirus) experimentally spiked into the samples. The fate of the two enteric viruses after concentration by zebra mussels was also investigated.

\section{Materials and methods}

\subsection{Water sampling}

Samples were collected from the Nosedo (Milan, Italy) wastewater treatment plant (WWTP) that receives wastewater from $1,250,000$ IE, with a negligible industrial contribution. It performs a conventional physical-biological-chemical treatment sequence that includes pre-treatments, primary settling, biological treatment by activated sludge, secondary settling, and filtration. This treatment sequence is followed by disinfection with peracetic acid. Sampling was performed after the secondary settling of the effluent, to better mimic the conditions of many WWTPs not provided with filtration and disinfection. These WWTPs discharge suspended solids that can feed zebra mussels, thus creating favorable conditions to their growth. Five samplings were performed and samples were refrigerated at $4{ }^{\circ} \mathrm{C}$ until the microbiological analyses were carried out, within $24 \mathrm{~h}$.

\subsection{D. polymorpha sampling}

Zebra mussels were collected during Spring 2013 by scuba divers from Lake Lugano, located at the Italy-Switzerland border. Acclimation of mussels was performed by keeping the bivalves in a large-mesh nylon net immersed in a beaker containing $300-\mathrm{mL}$ of the effluent sample, and slowly stirred. Ten mussels (around 2-cm long) were used for each experiment. The net was laid over a stainless-steel grid at around $2 \mathrm{~cm}$ from the bottom (Fig. 1) and the beakers were kept at room temperature (around $23^{\circ} \mathrm{C}$ ).

\subsection{Cells}

Green monkey kidney cells (Vero) were grown in Dulbecco's Modified Eagle's Medium (DMEM) supplemented with 10\% heat-inactivated newborn calf serum (CS; Gibco Life Technologies, Grand Island, NY, USA), $100 \mathrm{U} / \mathrm{mL}$ penicillin and $100 \mathrm{mg} / \mathrm{mL}$ streptomycin (P/S). Macaca mulatta fetal kidney cells (MA104) were grown in the same medium except that fetal calf serum (FCS; Gibco Life Technologies) was used.

\subsection{Viruses}

The poliovirus type I (attenuated Sabin strain from our lab) and the simian SA11 rotavirus were used. Every sample of the poliovirus- or the rotavirus-inoculated water was filtered through a $0.22-\mu \mathrm{m}$ membrane before titration. Titration was performed in triplicate on Vero and 


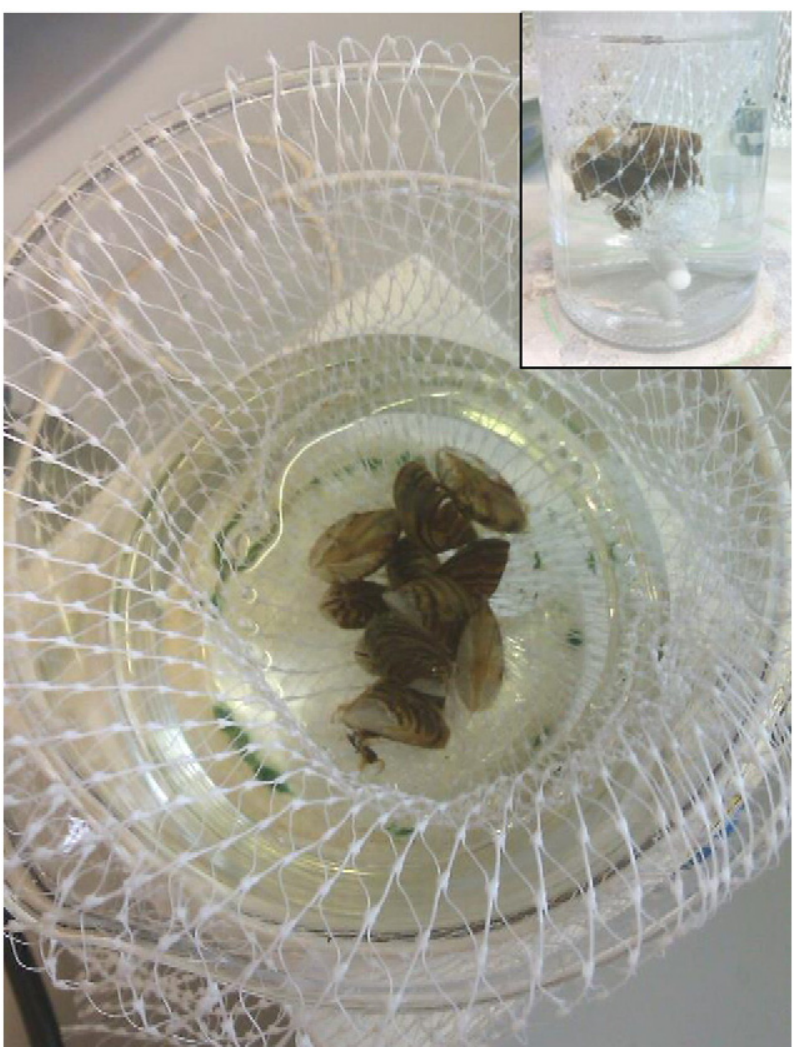

Fig. 1. Beaker containing $D$. polymorpha. During the experiment, zebra mussels were slowly stirred at room temperature in a large-mesh nylon net.

MA104 cells, respectively, to detect alive viruses. Negative controls were carried out using unspiked water.

For poliovirus titration, cell monolayers were infected with serial dilutions of the samples for $1 \mathrm{~h}$ at $37^{\circ} \mathrm{C}$ before adding the complete medium with 5\% CS and 0.7\% LE agarose (SeaKem, FMC BioProducts, Rockland, ME), as already described (La Colla et al., 1970). Briefly, after a further incubation at $37^{\circ} \mathrm{C}$ for 2 days, lysis plaques were revealed after $16-18 \mathrm{~h}$ with $1.5 \%$ neutral red. The percent reduction of the poliovirus titer was calculated by comparison with the control, where zebra mussels were not present.

For rotavirus, titration was performed as already described (Ruggeri and Greenberg, 1991). Briefly, cells were plated on 96-well plates overnight at $37^{\circ} \mathrm{C}$ and washed with serum-free DMEM before infection. After activation with $5 \mu \mathrm{g} / \mathrm{mL}$ acetylated trypsin (Sigma, St. Louis, MO, USA) for $30 \mathrm{~min}$ at $37^{\circ} \mathrm{C}$, cells were infected with serially diluted samples, and incubated for $16-20 \mathrm{~h}$ at $37^{\circ} \mathrm{C}$. The cells were then washed with $\mathrm{Ca}^{++}$- and $\mathrm{Mg}^{++}$-free phosphate-buffered saline $\left(\mathrm{PBS}^{-}\right.$) before treating with $\mathrm{PBS}^{-} / \mathrm{MetOH} 1: 1$, and fixing with $100 \%$ MetOH at -20 ${ }^{\circ} \mathrm{C}$ for 20-30 min. After air-drying, the cells were washed twice with $\mathrm{PBS}^{-}$at room temperature before incubation for $2.5 \mathrm{~h}$ a $37^{\circ} \mathrm{C}$ with the primary 1:1500-diluited rabbit anti-rotavirus antibody. After two washes in PBS $^{-}$, the goat anti-rabbit horseradish peroxidase (HRP)conjugated 1:200-diluted antibody (Sigma) was added for $1 \mathrm{~h}$ at 37 ${ }^{\circ} \mathrm{C}$. Two further washes in $\mathrm{PBS}^{-}$were performed before adding $100 \mathrm{mM}$ NaAcetate $\mathrm{pH} 5.5$ for $10 \mathrm{~min}$ at room temperature. Foci were viewed at the optical microscope after adding a solution of 3-amino-9 ethylcarbazole (AEC, Sigma) for 15 to $40 \mathrm{~min}$ in the dark, until a specific color was developed. The percent reduction of the rotavirus titer was calculated as described for poliovirus. The experiments were repeated three/four times which were requested to set up the poliovirus and rotavirus concentrations to be spiked according to the different number of D. polymorpha and volume of water used. Only the most reliable experiment is shown, which was performed in triplicate.

\subsection{E. coli counting}

E. coli counting was performed by membrane filtration method (APHA/AWWA/WEF) (APHA, 1998), using $0.45 \mu \mathrm{m}$ pore size cellulose nitrate membranes (Sartorius Stedim Biotech, GmbH, Goettingen, Germany) and chromogenic agar growth medium (EC X-GLUC agar, Biolife Italiana SrL, Milan, Italy). Inoculated plates were incubated at $44{ }^{\circ} \mathrm{C}$ for $24 \mathrm{~h}$ and $\mathrm{E}$. coli concentration was expressed as colonyforming units (cfu)/100 mL sample. The percent of $E$. coli removal was calculated with reference to the blank, with no mussels, at the same sampling times. Five replicates were performed.

\subsection{Determination of poliovirus and rotavirus removal by D. polymorpha}

Two test beakers were prepared per each virus, one with D. polymorpha and the other in the absence of the bivalves. The beakers were filled with $300 \mathrm{~mL}$ of the effluent water and then spiked to reach a final titer of $5 \times 10^{4}$ plaque-forming units ( $\left.\mathrm{pfu}\right) / \mathrm{mL}$ for poliovirus and $3.7 \times 10^{3}$ focus-forming units ( $\left.\mathrm{ffu}\right) / \mathrm{mL}$ for rotavirus. The titers were experimentally determined previously to give the adequate concentration both for the amount of water and the number of $D$. polymorpha to make the virus detectable after being in contact with the bivalve. The virusspiked effluent was slowly stirred for $15 \mathrm{~min}$, then the mussels were transferred from the acclimation container to the test beakers. Spikedeffluents with no mussels were used as a control. Samples were collected from the test beakers after $15 \mathrm{~min}\left(\mathrm{~T}_{0}\right), 4,6,8$ and $24 \mathrm{~h}\left(\mathrm{~T}_{4}, \mathrm{~T}_{6}, \mathrm{~T}_{8}\right.$ and $\mathrm{T}_{24}$, respectively) for poliovirus and after $4,8,12$, and $24 \mathrm{~h}\left(\mathrm{~T}_{4}, \mathrm{~T}_{8}, \mathrm{~T}_{12}\right.$ and $\mathrm{T}_{24}$, respectively) for rotavirus. Poliovirus and rotavirus samples were kept at $-80^{\circ} \mathrm{C}$ and at $4{ }^{\circ} \mathrm{C}$, respectively, till they were analyzed after filtration through $0.22 \mu \mathrm{m}$ membranes. The percentage of virus removal by $D$. polymorpha from the water phase was calculated at the same sampling times with reference to the control.

Viral presence was also determined in the pseudofecal or fecal discharge material for the three days after the experiment, during which the mussels were kept in tap water and fed with Spirulina spp. algae. Briefly, after two washes with $100 \mathrm{~mL}$ of maintenance medium to remove the residual inoculum, some water was added for 1 day (200$\mathrm{mL}$ ) to obtain feces and pseudofeces. An aliquot of water was then collected, filtered and analyzed before adding $100 \mathrm{~mL}$ of water containing Spirulina spp. Two days later, the water was centrifuged at $2000 \times g$ to separate feces, which were then resuspended in $3 \mathrm{~mL}$ of Earle BSS, filtered through $0.45 \mu \mathrm{m}$ membrane, and titrated.

The search for residual virus was extended to the soft-tissue homogenates of zebra mussels. Briefly, 150 or $30 \mathrm{~mL}$ of the effluent were spiked with either $5 \times 10^{4} \mathrm{pfu} / \mathrm{mL}$ of poliovirus or with $3.7 \times 10^{3} \mathrm{ffu} /$ $\mathrm{mL}$ of rotavirus and left with the bivalves for $24 \mathrm{~h}$. The zebra mussels were then removed from the effluent, and, after $48 \mathrm{~h}$ in tap water within a beaker with extensive stirring, the tissues were mechanically desegregated with scissors, as already performed for primary cell culture preparations from chick embryos (Temin and Rubin, 1958). Two $\mathrm{mL}$ of serum-free medium were then added to the homogenate, which was centrifuged at $2100 \times \mathrm{g}$ for $15 \mathrm{~min}$ at $4{ }^{\circ} \mathrm{C}$. The supernatant was then frozen at $-80^{\circ} \mathrm{C}$ until titration was performed.

\subsection{Determination of E. coli removal by $D$. polymorpha}

After acclimation, the net containing D. polymorpha was transferred into $300-\mathrm{mL}$ beakers containing the effluent samples. The effluent sample with no mussels was used as a blank. E. coli colonies were counted after 4,24 and $48 \mathrm{~h}$ contact time $\left(\mathrm{T}_{4}, \mathrm{~T}_{24}\right.$ and $\mathrm{T}_{48}$, respectively).

\subsection{Statistical analyses}

Statistical analyses were performed using the one-way ANOVA parametric test with the Bonferroni post-hoc analysis of variance, and the 

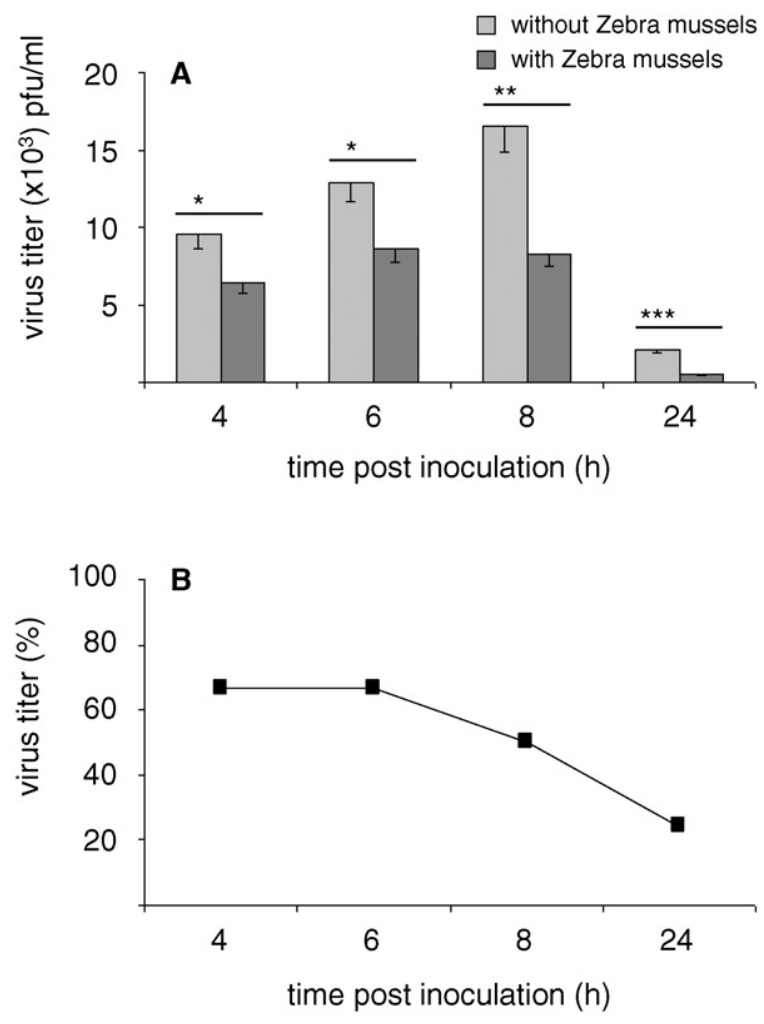

Fig. 2. Reduction of poliovirus titer by D. polymorpha. The effluent was spiked with poliovirus in the presence or absence of $D$. polymorpha and analyzed at $T_{4}, T_{6}, T_{8}$, and $T_{24}$ (panel A). A significant reduction of the viral titer can be observed over time in the effluent containing the bivalves (panel B) compared to the titer found in the effluent without D. polymorpha. The average of three replicates is shown.

GraphPad Prism 5 software. The significance was set as $\mathrm{p}<0.05\left({ }^{*}\right)$, $\left.\mathrm{p}<0.01{ }^{* *}\right), \mathrm{p}<0.001\left(^{* * *}\right)$.

\section{Results}

\subsection{Zebra mussels can reduce poliovirus titer from wastewater}

To verify the ability of zebra mussels to decrease the amount of poliovirus, the effluent water experimentally spiked with the virus in the presence or absence of $D$. polymorpha was analyzed at different times post inoculation (p.i.) (Fig. 2A). Preliminary experiments were performed to determine the poliovirus titer to be spiked to detect a decrease by zebra mussels in experimentally-tested volumes (data not shown). The final poliovirus concentration was thus established as $5 \times 10^{4} \mathrm{pfu} / \mathrm{mL}$. A constant and significant $33.3 \%$ reduction of the virus titer was found $4 \mathrm{~h}\left(\mathrm{~T}_{4}, \mathrm{p}<0.05\right)$ and $6 \mathrm{~h}\left(\mathrm{~T}_{6}, \mathrm{p}<0.01\right)$ p.i., that further increased at $8 \mathrm{~h}\left(\mathrm{~T}_{8}, 49.7 \%, \mathrm{p}<0.001\right)$ and $24 \mathrm{~h}$ p.i. $\left(\mathrm{T}_{24}, 75.7 \%\right)$ (Fig. $2 \mathrm{~A}$ and $\mathrm{B}$ ). No virus was detectable when looking for endogenous live poliovirus in the effluent water before virus spiking. Negative results were also obtained from $D$. polymorpha feces and pseudofeces, whereas $3.4 \times 10^{4} \mathrm{pfu} / \mathrm{mL}$ of poliovirus were found in the $2-\mathrm{mL}$ total mussel homogenate supernatant, corresponding to $0.9 \%$ of the spiked virus, $48 \mathrm{~h}$ after washes in clear water (Table 1). Controls using unspiked wastewater were always negative, as expected.

\subsection{Rotaviruses are almost completely removed from wastewater by zebra mussels}

As rotaviruses might be present in the effluent water, the ability of D. polymorpha to reduce their contamination was verified after experimental spiking (Fig. 3A). Preliminary experiments were also performed to determine the rotavirus titer to be spiked and detect its decrease by zebra mussels in tested volumes (data not shown) before using the final concentration of $3.7 \times 10^{3}$ focus-forming units $(\mathrm{ffu}) / \mathrm{mL}$. An initial reduction was observed $4 \mathrm{~h}$ p.i. $\left(\mathrm{T}_{4}, 74.5 \%, \mathrm{p}<0.001\right)$, that increased $8 \mathrm{~h}$ $\left(\mathrm{T}_{8}, 88.6 \%, \mathrm{p}<0.001\right), 12 \mathrm{~h}\left(\mathrm{~T}_{12}, 99.0 \%, \mathrm{p}<0.001\right)$, and $24 \mathrm{~h}$ p.i. $\left(\mathrm{T}_{24}, 96 \%\right.$, $\mathrm{p}<0.01$ ) (Fig. $3 \mathrm{~A}$ and $\mathrm{B}$ ). No endogenous rotavirus was found in the effluent before virus spiking nor when rotavirus was searched in the mussel homogenate supernatant (Table 1). Controls using unspiked wastewater were always negative, as expected.

\subsection{Zebra mussels significantly reduce endogenous E. coli counts in the effluent}

Although the number of $E$. coli colonies decrease spontaneously overtime also in the absence of zebra mussels (Fig. 4A), a significant efficiency in enterobacterial removal was found starting from $4 \mathrm{~h}$ after exposure to $D$. polymorpha $\left(\mathrm{T}_{4}, 83.1 \%, \mathrm{p}<0.001\right)$. The decrease was even higher at 24 and $48 \mathrm{~h}\left(\mathrm{~T}_{24}\right.$ and $\mathrm{T}_{48} ; 98.6$ and 99.4\%; $\left.\mathrm{p}<0.001\right)$, when E. coli colonies were found in very limited numbers $(8 \mathrm{cfu} / 100 \mathrm{~mL})$ (Fig. 4A and B).

\section{Discussion}

Several studies already showed that zebra mussels can accumulate or remove pathogenic microorganisms from water bodies. However, only a few studies were related to viruses. A reduced viral infectivity was shown in wood ducks (Aix sponsa) inoculated intranasally with water spiked with avian influenza virus, previously filtered by Corbicula fluminea (Faust et al., 2009), which allowed bird survival. It was also demonstrated that zebra mussels could accumulate avian influenza virus from wastewaters for an extended period (Stumpf et al., 2010), after which the virus was still detectable inside the mussels even after transfer to freshwater.

In the present study, samples of treated effluents were used to evaluate the capability of $D$. polymorpha to remove or inactivate endogenous E. coli or spiked enteric viruses from wastewaters. Our results demonstrate that zebra mussels can reduce significantly: (1) poliovirus titer after $24 \mathrm{~h}$; (2) rotavirus titer after $4 \mathrm{~h}$; and (3) E. coli counts by about $1.5 \mathrm{log}$ after $4 \mathrm{~h}$ and nearly completely after $24 \mathrm{~h}$.

Differently from E. coli, which was already present in the effluents, the enteric viruses had to be spiked into the effluent samples. In particular, the live-attenuated poliovirus Sabin strain was utilized, as no live and titratable virus can be recovered from wastewaters, due to the use of the inactivated poliovirus Salk strain for the current vaccination protocols. Although unexpected, the increase of poliovirus titer up to $8 \mathrm{~h}$ after spiking, in the absence of zebra mussels, can be ascribed to the frequent presence of poliovirus pseudo-crystals (Kawanishi, 1978) that can desegregate over time, whereas the sharp decrease in viral titer at $24 \mathrm{~h}$ was probably caused by environmental factors, that favored poliovirus inactivation. Conversely, after rotavirus spiking, the titer in wastewater spontaneously decreased over time, also in the absence of zebra mussels, whereas, in the presence of $D$. polymorpha, a more significant reduction was observed starting from $4 \mathrm{~h}$ contact time.

Few and sometimes contrasting data are available about the longterm survival of pathogens inside the bivalves and their release in the aquatic environment. Although zebra mussels may be an important reservoir for bacteria, it was demonstrated that Aeromonas species potentially pathogenic for humans (Aeromonas jandaei, Aeromonas jandaei veronii, Aeromonas jandaei salmonicida, Aeromonas jandaei hydrophila and Aeromonas jandaei media) were also lethal to this species ( $\mathrm{Gu}$ and Mitchell, 2002; Maki et al., 1998). In our study, by analyzing the fate of the two spiked enteric viruses, a considerable amount of the inoculum was found to be removed and concentrated by mussel filtration, as demonstrated by viral detection in the liquid phase of the mussel homogenate.

The remaining live poliovirus was irrelevant outside or inside the zebra mussels, and we hypothesize that the inoculum might have 
Table 1

Virus titer in wastewater and zebra mussel homogenate.

\begin{tabular}{|c|c|c|c|c|c|}
\hline & $\begin{array}{l}\text { Endogenous virus } \\
\text { in effluent water }\end{array}$ & $\begin{array}{l}\text { Total virus in feces } \\
\text { and pseudofeces }\end{array}$ & $\begin{array}{l}\text { Spiked virus } \\
(\mathrm{pfu} / \mathrm{ml})\end{array}$ & $\begin{array}{l}\text { Total spiked } \\
\text { virus ( } \mathrm{pfu})\end{array}$ & $\begin{array}{l}\text { Total virus in mussel } \\
\text { homogenate (pfu) }\end{array}$ \\
\hline Poliovirus & n.d. & n.d. & $5.0 \times 10^{4}$ & $7.5 \times 10^{6 a}$ & $6.8 \times 10^{4}$ \\
\hline Rotavirus & n.d. & n.d. & $3.7 \times 10^{3}$ & $1.0 \times 10^{6 b}$ & n.d. \\
\hline
\end{tabular}

n.d., not detectable.

$150 \mathrm{ml}$ were used.

b $30 \mathrm{ml}$ were used.

been either inactivated by the wastewater or by mussel-released virucidal factors, making the virus undetectable by the used live-virus plaque-counting assay. Live rotavirus was also undetectable in the liquid phase of the soft-tissue homogenate for the same reasons as for poliovirus. However, its absence might also be due to the natural high liability of rotavirus during the experimental manipulations. It is important to note that rotavirus cannot be frozen/thawed several times without a clear reduction of the viral titer and that a low titer can generally be obtained during its production on in-vitro cell cultures. This is also the reason why a lower concentration and a smaller volume of effluent water were used for rotavirus than for poliovirus during the experimental design.

Although in studies regarding enterobacterial removal from wastewater by $D$. polymorpha a $50 \%$ reduction was found after $24 \mathrm{~h}$ and almost $100 \%$ after 48 h (Selegean et al., 2001), our results showed a reduction of already $83.1 \%$ and $98.6 \%$ at $\mathrm{T}_{4}$ and $\mathrm{T}_{2} 4$, respectively, and almost $100 \%$ at $\mathrm{T}_{48}$. In the control samples, where zebra mussels were absent, the overtime decrease in E. coli colonies was slower, and can be due to the inactivation by toxic factors present in the wastewater.

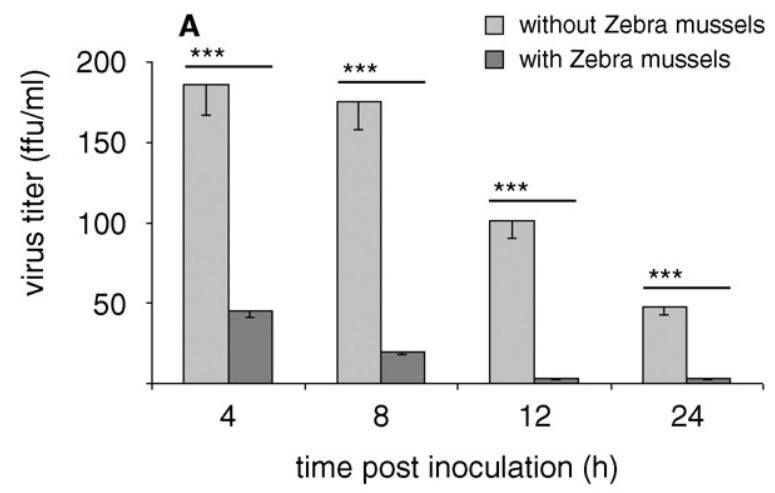

B

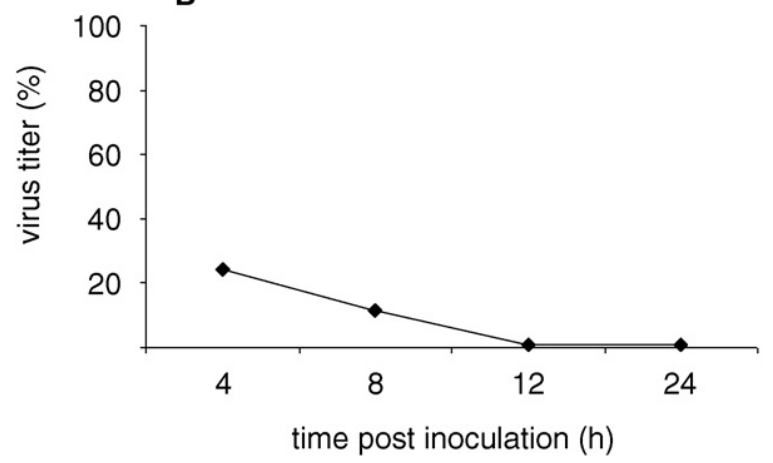

Fig. 3. Reduction of rotavirus titer by $D$. polymorpha. The effluent was spiked with rotavirus in the presence or absence of $D$. polymorpha and analyzed at $\mathrm{T}_{4}, \mathrm{~T}_{8}, \mathrm{~T}_{12}$, and $\mathrm{T}_{24}$ (panel A). A dramatic reduction of the viral titer can be already observed in the effluent containing the bivalves at $\mathrm{T}_{4}$ that was more evident at $\mathrm{T}_{8}$, and almost reached $100 \%$ at $\mathrm{T}_{12}$ and $\mathrm{T}_{24}$ (panels A and B). The average of three replicates is shown.
Since viruses are intracellular parasites that can be released in the environment, it is not unlikely that bivalves may concentrate viruses from the wastewater and may act as a source of contamination. Zebra mussels are an important food source for some fish and waterbirds (Tucker et al., 1996; Zimmermann et al., 1997), and viruses might be transmitted to waterbirds, which are the natural predators of $D$. polymorpha. However, our data suggest that zebra mussels cannot only retain enteric viruses, but also inactivate them, thus preventing avian-to-human transmission. In effluent-dominated streams, if the conditions provide the suitable habitat for their presence and growth, the ability of $D$. polymorpha to filter and inactivate pathogens might have positive effects to control health risks for animals and human beings.

\section{Conclusions}

Overall, although the number of $D$. polymorpha we used may not be representative of the zebra mussel density in watercourses, our preliminary data seem to demonstrate the positive effects of this invasive species on the hygienic conditions of surface waters. Zebra mussels were
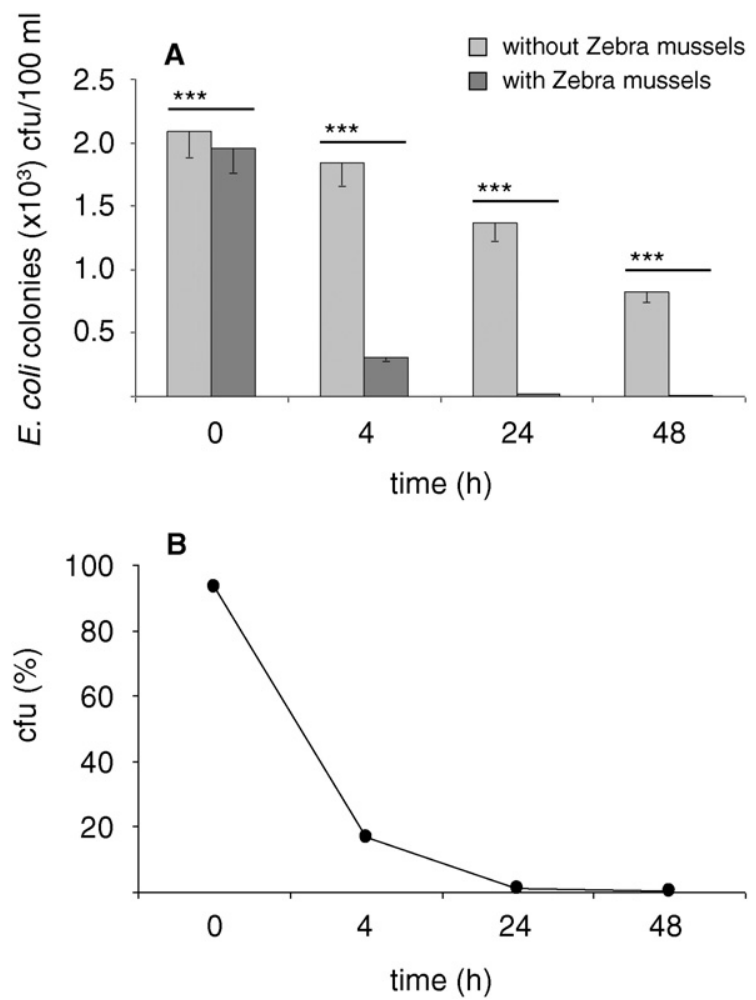

Fig. 4. Reduction of endogenous $E$. coli colony numbers by $D$. polymorpha. Analyses were carried out at $\mathrm{T}_{0}, \mathrm{~T}_{4}, \mathrm{~T}_{24}$, and $\mathrm{T}_{48}$ (panel $\mathrm{A}$ ) in the presence or absence of $D$. polymorpha. A significant efficiency in bacterial removal was found starting from $\mathrm{T}_{4}$ after exposure to zebra mussels, which reached almost $100 \%$ at $\mathrm{T}_{24}$ and $\mathrm{T}_{48}$ (panel B). 
able to remove two enteric viruses (the poliovirus and rotavirus), probably not in the way that bacteria are removed, given the viral size. To our knowledge, the uptake and inactivation of poliovirus and rotavirus by zebra mussels has never been reported.

This invasive species can thus be useful to inactivate $E$. coli, reduce viral concentrations and decrease the levels of some pollutants resistant to the traditional treatments of WWTPs, as also shown by other studies carried out by our group in the pilot-plant built at Nosedo WWTP (Binelli et al., 2014; Magni et al., 2015). These three studies also seem to share similar results, in that better performances were obtained using treatments with longer exposure times and low water flow. The next step should be therefore the large-scale use in small reservoirs with biofiltration techniques, such as the phytodepuration and lagooning systems, where the permanence time is generally a-few day long.

As zebra mussels are often considered an alien species, their use for these purposes will require containment measures to avoid diffusion in the surrounding water systems both of adult mussels and veliger larvae. Thus, the introduction of this invasive species for water quality management is not suggested, but rather their attractive qualities in controlled systems should be considered in areas where they are already growing, following specific precautions, such as the installation of narrow grids or sand filters in the outlet.

Native bivalves, such as the Unionidae, could be one of the best solutions, if they were not an endangered species, unsuitable for the above-mentioned purposes. Preliminary studies should therefore include the search for a rapid method for their growth and to produce a large amount of zebra mussels, necessary for waste treatment. A lessexpensive method to eliminate the bivalve biomass contaminated by xenobiotics and pathogens should also be found out.

\section{Notes}

The authors declare no competing financial interests.

\section{Acknowledgments}

The research was partially funded by Fondazione CARIPLO, Project no. 2010.2098 "Utilizzo di biofiltratori naturali per la depurazione civile e industriale", 2010. We also thank Giovanni Ianiro (I.S.S.) for the rotavirus reagents.

\section{References}

Ackerman, J.D., 1999. Effect of velocity on the filter feeding of dreissenid mussels (Dreissena polymorpha and Dreissena bugensis): implications for trophic dynamics. Can. J. Fish. Aquat. Sci. 56, 1551-1561.

APHA, A.\&.W., 1998. Standard Methods for the Examination of Water and Wastewater. American Public Health Association/American Water Works Association/Water Environment Federation, Washington, DC, USA

Baldwin, B.S., Mayer, M.S., Dayton, J., Pau, N., Mendilla, J., Sullivan, M., Moore, A., Ma, A., Mills, E.L., 2002. Comparative growth and feeding in zebra and quaggamussels (Dreissena polymorpha and Dreissena bugensis): implications for North American lakes. Can. J. Fish. Aquat. Sci. 59, 680-694.

Bervoets, L., Voets, J., Covaci, A., Chu, S.G., Qadah, D., Smolders, R., Schepens, P., Blust, R., 2005. Use of transplanted zebra mussels (Dreissena polymorpha) to assess the bioavailability of microcontaminants in Flemish surface waters. Environ. Sci. Technol. 39, $1492-1505$.

Binelli, A., Magni, S., Soave, C., Marazzi, F., Zuccato, E., Castiglioni, S., Parolini, M., Mezzanotte, V., 2014. The biofiltration process by the bivalve $D$. polymorpha for the removalof some pharmaceuticals and drugs of abuse from civil wastewaters. Ecol. Eng. 71, 710-721.

Claudi, R., Mackie, G.L., 1993. Practical Manual for Zebra Mussel Monitoring and Control. Lewis Publishers, Boca Raton, p. 201.

De Jonge, M., Belpaire, C., Geeraerts, C., De Cooman, W., Blust, R., Bervoets, L., 2012. Ecological impact assessment of sediment remediation in a metal-contaminated lowland river using translocated zebra mussels and resident macroinvertebrates. Environ. Pollut. 171, 99-108.
Faust, C., Stallknecht, D., Swayne, D., Brown, J., 2009. Filter-feeding bivalves can remove avian influenza viruses from water and reduce infectivity. Proc. Biol. Sci. 276 3727-3735

Flannery, J., Keaveney, S., Rajko-Nenow, P., O'Flaherty, V., Doré, W., 2013. Norovirus and FRNA bacteriophage determined by RT-qPCR and infectious FRNA bacteriophage in wastewater and oysters. Water Res. 47, 5222-5231.

Frischer, M.E., Nierzwicki-Bauer, S.A., Parsons, R.H., Vanthanodorn, K., Waitkus, K.R., 2000 Interactions between zebra mussels (Dreissena polymorpha) and microbial communities. Can. J. Fish. Aquat. Sci. 57, 591-599.

$\mathrm{Gu}$, J.D., Mitchell, R., 2002. Indigenous microflora and opportunistic pathogens of the freshwater zebra mussel, Dreissena polymorpha. Hydrobiologia 474, 81-90.

Kalchev, R., Beshkova, M., Botev, I., Kalcheva, H., Kozuharov, D., Trichkova, T., 2013. Effect of Dreissena polymorpha (bivalvia: Dreissenidae) on physicochemical characteristics of Zhrebchevo reservoir (central Bulgaria). C. R. Acad. Bulg. Sci. 66, 1571-1578.

Kawanishi, M., 1978. Intranuclear crystal formation in picornavirus-infected cells. Arch. Virol. 57, 123-132.

La Colla, P., De Giuli Morghen, C., Cioglia, A.M., Zuffardi, O., Loddo, B., 1970. The mechanism of guanidine inhibition of poliovirus growth in vitro. Life Sci. 9, 1351-1358.

Love, D.C., Lovelace, G.L., Sobsey, M.D., 2010. Removal of Escherichia coli, Enterococcus fecalis, coliphage MS2, poliovirus, and hepatitis A virus from oysters (Crassostred virginica) and hard shell clams (Mercinaria mercinaria) by depuration. Int. J. Food Microbiol. 143, 211-217.

Magni, S., Parolini, M., Soave, C., Marazzi, F., Mezzanotte, V., Binelli, A., 2015. Removal of metallic elements from real wastewater using zebra mussel bio-filtration process. J. Environ. Chem. Eng. http://dx.doi.org/10.1016/j.jece.2015.01.017.

Maki, J.S., Patel, G., Mitchell, R., 1998. Experimental pathogenicity of Aeromonas spp. for the zebra mussel, Dreissena polymorpha. Curr. Microbiol. 36, 19-23.

de Mesquita, M.M., Evisom, L.M., West, P.A., 1991. Removal of faecal indicator bacteria and bacteriophages from the common mussel (Mytilus edulis) under artificial depuration conditions. J. Appl. Bacteriol. 70, 495-501.

Palos Ladeiro, M., Aubert, D., Villena, I., Geffard, A., Bigot, A., 2014. Bioaccumulation of human waterborne protozoa by zebra mussel (Dreissena polymorpha): interest for water biomonitoring. Water Res. 48, 148-155.

Peck, M.R., Labadie, P., Minier, C., Hill, E.M., 2007. Profiles of environmental and endogenous estrogens in the zebra mussel Dreissena polymorpha. Chemosphere 69, 1-8.

Piesik, Z., 1983. Biology of Dreissena polymorpha (Pall.) settling on stylon nets and the role of this mollusc in eliminating the seston and the nutrients from the watercourse. Pol. Arch. Hydrobiol. 30, 353-361.

Richter, A.F., 1986. Biomanipulation and its feasibility for water quality management in shallow eutrophic water bodies in The Netherlands. Hydrobiol. Bull. 20, 165-172.

Ruggeri, F.M., Greenberg, H.B., 1991. Antibodies to the trypsin cleavage peptide VP8* neutralize rotavirus by inhibiting binding of virions to the target cells in culture. J. Virol 65, 2211-2219.

Sanz-Ronda, F.J., Lopez-Saenz, S., San-Martin, R., Palau-Ibars, A., 2014. Physical habitat of zebra mussel (Dreissena polymorpha) in the lower Ebro River (Northeastern Spain): influence of hydraulic parameters in their distribution. Hydrobiologia 735, 137-147.

Schloesser, D.W., Nalepa, T.F., 1994. Dramatic decline of unionid bivalves in offshore waters of western lake erie after infestation by the zebra mussel, Dreissena polymorpha Can. J. Fish. Aquat. Sci. 51, 2234-2242.

Schloesser, D.W., Schmuckal, C., 2013. Bibliography of Dreissena polymorpha (zebra mussels) and Dreissena rostriformis Bugensis (QUAGGA mussels): 1989 to 2011. J. Shellfish Res. 31, 1205-1263.

Schwab, K.J., Neill, F.H., Estes, M.K., Metcalf, T.G., Atmar, R.L., 1998. Distribution of norwalk virus within shellfish following bioaccumulation and subsequent depuration by detection using RT-PCR. J. Food Prot. 61, 1674-1680.

Selegean, J.P.W., Kusserow, R., Patel, R., Heidtke, T.M., Ram, J.L., 2001. Using zebra mussels to monitor Escherichia coli in environmental waters. J. Environ. Qual. 30, 171-179.

Stankovic, S., Jovic, M., 2013. Native and invasive mussels. In: Nowak, J., Kozlowski, M. (Eds.), Mussels: Ecology, Life Habits and Control (Marine Biology). Nova Science Pub Inc., pp. 1-35.

Stumpf, P., Failing, K., Papp, T., Nazir, J., Boehm, R., Marschang, R.E., 2010. Accumulation of a low pathogenic avian influenza virus in zebra mussels (Dreissena polymorpha). Avian Dis. 54, 1183-1190.

Temin, H.M., Rubin, H., 1958. Characteristics of an assay for Rous sarcoma virus and Rous sarcoma cells in tissue culture. Virology 6, 669-688.

Tucker, J.K., Cronin, F.A., Soergel, D.W., Theiling, C.H., 1996. Predation on zebra mussels (Dreissena polymorpha) by common carp (Cyprinus carpio). J. Freshw. Ecol. 11, 363-372.

Voets, J., Talloen, W., de Tender, T., van Dongenc, S., Covaci, A., Blust, R., Bervoets, L., 2006 Microcontaminant accumulation, physiological condition and bilateral asymmetry in zebra mussels (Dreissena polymorpha) from clean and contaminated surface waters. Aquat. Toxicol. 79, 213-225.

Winters, A.D., Marsh, T.L., Faisal, M., 2011. Heterogeneity of bacterial communities within the zebra mussel (Dreissena polymorpha) in the Laurentian Great Lakes basin. J. Great Lakes Res. 37, 318-324.

Zimmermann, G., Dietrich, D.R., Schmid, P., Schlatter, C., 1997. Congenerspecific bioaccumulation of PCBs in different water bird species. Chemosphere 34, 1379-1388. 